コンファレンスレポート

\title{
第13回量子エレクトロニクス国際会議（IQEC） レーザーとエレクトロオフティクス会議（CLEO）
}

山中千代衛*.吉田国 雄*. 佐々木孝友**

\author{
XIII International Conference on Quantum Electronics \\ Conference on Lasers and Electro-Optics
}

Chiyoe YAMANAKA*, Kunio YOSHIDA* and Takatomo SASAKI**

IQEC’84は1984年 6 月18日より21日, CLEO ’84は1日おくれで19日より22日まで米国カリ フォルニア，オレンジカウンティのアナハイム で併催された。

よくしられたようにIQECはレーザー関連の 最も権威のある国際会議で歴史も古く, 取り扱 う領域は基礎的，学術的分野を中心としている。 今回は採択論文 241 , 期限後受付論文 23 であっ た。応募論文に対する採択率は $40 \%$, 招待論文 は45篇である。

CLEOは会議名が示すようにより工業応用, 技術サイドの会議であり, きわめて広い分野を カバーしている。それでも光ファイバーや光機 器などを専問とする別の会議が開催されつつあ り, この分野の発展は留る処をしらぬように見 える。今回は採択論文 379 , 期限後受付論文 21 , 採択率は $80 \%$, 招待論文は 56 篇である。両会議 に共通の招待論文は13篇であった。

両会議は別々の委員会で運営されており，I QECに関しては今回のQE Joint委員長はベル のJ. A. Glordmaine, 実行委員長は同じくベル の H. Kogelnik とカリフォルニア大の Y. R. Shen, プログラム委員長がロチェスター大のM.

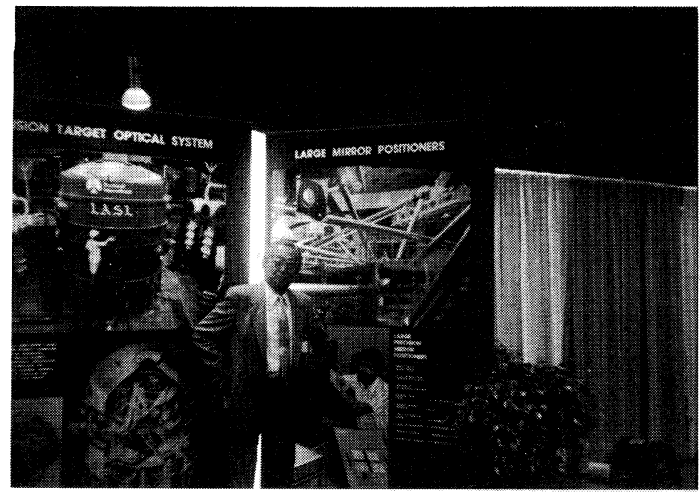

IQEC・CLEOにおける展示会

C. Richardsonとコーネル大のC. L. Tangであ る。恒例によって次会の実行委員長はプログラ 厶委員長がつとめることになっている。日本の プログラム委員長は東工大の末松教授と筆者で ある。

CLEOに関しては実行委員長がスペクトライ ジクス社の D. T. Hodges とベルの W. T. Silfvast, プログラム委員長が IBM の G.C. Bjorklundとジェットプロパルジョンの E. D. Hinkley，展示委員長はニューポート社の T. $\mathrm{S} . \mathrm{Hsu}$ ，日本のザブ委員長は日立の武田氏であ る。CLEOは IQ E C と異ってプログラム委員

*大阪大学レーザー核融合研究センター（５565 吹田市山田丘 2-6）

**大阪大学工学部電気教室（５６5 吹田市山田丘1-2）

* Institute of Laser Engineering, Osaka University(2-6 Yamadaoka, Suita, Osaka 565)

* * Fuculty of Engineering, Osaka University (1-2 Yamadaoka Suita, Osaka 565) 
会を専問別の10サブ委員会に分けて運営してい る。

両会議を併催するのは経済的理由によるもの で，運営は全く別々に行われ，互に協力してカ バーし合っている。とくに自由電子レーザーと レーザー医用には共催シンポジウムが設けられ たし，またC.H. Townse, R. P. Feyman，J. W. Goodman, A. J. DeMeria の特別講演も共 催であった。大規模な展示会が開催され，基礎 から応用まで米国の層の厚さを十二分に公示し ていた。

筆者はIQECの実行委員会，プログラム委員 会およびQE Joint委員会に出席し，論文選 定 と次回以降の会議の検討に参画した。IQEC は 2 年毎の開催であり，CLEOは毎年開催である から，1985年はCLEO単独でBaltimore，5月 21〜24日，1986年に IQEC，CLEO 併催が Sanfrancisco，1988年にはIQEC 単独で日本開 催の線が出ている。最終決定は10月末に行われ ることになっている。

今回は阪大レーザー研より筆者の外加藤教授, 中塚助教授, 佐々木助教授, 吉田講師が参加し 6 七ッション併列の会議を分担してカバーした。 またレーザー核融合と大出カレーザーに関して， 2 篇の招待講演を発表した。わが国からの寄与 はCLEOに関しては産業技術の展開に関連して, 多数の発表が行われたが，基礎分野，新領域を カバーするIQECにおいてはレーザー核融合な ど一部を除いては，わが国からの寄与が比較的 すくなく，最も新しい情報を呈供するはずの期 限後受付論文の応募は皆無であった。今後の対 応を考える上で十分反省を要することであろう。

それでは両会議の中から筆者の分担した調査 範囲である新レーザー，レーザー核融合，自由 電子レーザー，位相共役，レーザー同位体分離 に関し二三のトピックスを招介することにしよ う。

新レーザーのセッションではベルの $\mathrm{W} ＼textrm{T}$. SilfvastがHigh-gain lasers excited by inner shell photoionization from broadband soft Xray laser produced plasmasを発表。
$\mathrm{Cd}, \mathrm{Ag}, \mathrm{Zn}$ の $4 \mathrm{~d}$ 内款の遷移を用いるレーザー の基礎研究である。12eV のプラズマ黒体輻射 $300 \AA$ Aを用いると $10^{8} \mathrm{~W} / \mathrm{cm}^{2}, 10^{14}$ の軟X線光子が 出るので, これにより圧力 3 torr $の$ 気体 $10^{17} \mathrm{~cm}^{-3}$ の密度, イオン化断面積 $\sigma_{\mathrm{PI}} \sim 10^{17} \mathrm{~cm}^{2}$ に吸収さ せ, 誘導放出断面積 $\sigma_{\mathrm{STIM}}=10^{-13}$ にて

$$
e^{\sigma \mathrm{N} 1}=e^{10}, \quad N=10^{14}, \quad l=1 \mathrm{~cm}
$$

を得ると評価している。YAGとか $\mathrm{CO}_{2}$ レーザー 一でタングステンを照射し，X線を発生， S U $\mathrm{S}$ のヒートパイプで発生した $\mathrm{Cd}$ 蒸気に吸収さ せて $4416 \AA$, gain $40 \mathrm{~cm}^{-1} 0.1 \mathrm{~mJ}, 5 \mathrm{~kW}$ を得て いる。可視と紫外の tunable laser を用い, double transfer transitionで可視と紫外のチ ユーナブルレーザーを用いてVUV，XUVの発 振を得ている。

レーザー核融合のセッションでは筆者が最初 に座長をつとめたが，そこではロスアラモスの S. D. Rockwoodが米国の研究状況を報告した。 最も興味を引いたのは燃料ターゲットの分類に Direct, Indirect (radiation) Cannonball (hydrodynamic) と 3 種を上げ，大阪大学のキ ヤノンボールターゲットを公認したことである。 短波長レーザーの優位性を取り上げ， $\mathrm{CO}_{2}$ レー ザーAntaresでは200 kev近い高温電子の出現を 報じた。また L L Lのデーターとして小型プラ ズマと大型プラズマでは誘導ラマンやブリルア ン放射が全くちがうことを強調した。エネルギ 一輸送抑制因子 $f$ を 0.03 と評価するとともに形 状に依存すると述べている。質量アブレーショ ン率や圧力のデーターを上げ大阪のデーターを 引用している。N R Lの広帯域レーザーによる インコヒーレント実験にふれ，またX線変換の データーを与えた。 $\mathrm{CO}_{2}$ レーザー自身の将来に ついて質問したところ，磁気利用ターゲットで 当面研究をすすめ，高温電子制御を期待すると のことであった。

自由電子レーザーのシンポジウムは会議の目 玉の一つである。合計18篇の論文が 4 セッショ ンにわたって発表された。最初の座長はロスア ラモスのC. Brau， 3 年程前に筆者がロスアラ モスを訪問し，自由電子レーザーの視察をした 
時は, 研究所の十隅で小型ライナックの小規模 実験を始めたばかりであったが, 今や自由電子 レーザー開発の一方の旗頭として颯爽と登場し てきた。シンポジウムの内容を概観すると次の ようになる。

フランスのOrsayではJ. M. Ortegaによれば 20 年前の Storage ringを活用し，116〜225 M $\mathrm{eV}$ の加速で可視光 $6500 \AA$ A発振に成功している。 米国の Austin では理論的研究が M. N. Rosenbluthの指導でH. V. Wongにより行われ, サイクロトロン放射で電子速度分布の拡がりを 抑止するとともにポンデロ力で電子がトラップ されない条件を求めている。

TRWのJ. EdighofferはStanfordと協力し, $60 \mathrm{MeV}, 2.5 \mathrm{~A}$ peak, $4 \mathrm{ps}$ の電子バンチで 12.6 $\mathrm{m}$ のキャビティーを用い, テーパーウイグラに て1. $6 \mu$ 光を効率 $1.2 \%$ で発生している。

ベル研ではFIRレーザーの研究をマイクロト ロンを用いて実施している。E. D. Shaw によ れば $3 \mathrm{GHz}, 10 \mathrm{MW}$ の駆動で $100 \mathrm{kw}, 10 〜 40 \mathrm{ps}$ $100 \sim 400 \mu \mathrm{m}$ 波長光を得ている。これは Si応用 の目的を持っている。

LANLでは $6.9 \mathrm{~m}$ のキビティ $9 \sim 11 \mu \mathrm{m}$ 波長 の光を $30 \mathrm{ps} 5 \mathrm{MW}, 70 \mu \mathrm{s}, 3 \mathrm{~kW}$ の出力で実現 している。B. E. Newnam.によるとキャビティ 一長には最適值がある。

英国の計画も進展を見せており，Glassgow をはじめ全国協力ですすめられ $5 \mathrm{~m}$ のウイグラ 一で100 MeVの電子を使い $1 \mathrm{MW}, 50 \mathrm{ps}, 2$ $20 \mu \mathrm{m}$ の光を得ている。 $5 \mu \mathrm{s}$ では $100 \mathrm{~kW}$ となる。 磁界を制御してグリーン化, ブルー化の予定で ある。発表者はC.R. Pidgeon。

この他 NRL, UC Santababara, New mexico大, Milano大, Stanford大, BNLな どから基礎的なビーム波動相互作用の発表があ った。

位相共役に関しては, まずR. W. Hellworth のUse of phase conjugation for physical measurement という展望発表があり，ホログ ラムのアナロジーで 4 波混合位相共役の説明。 いろいろの物理計測, とくに 2 光子ドップラフ
リー分光への応用, 半導体中の電荷担体のトラ ップとか不純物イオンや励起色素の特性計測へ の利用が概説された。

一連の発表の中で注目をあびたのは英国, Imperial CollegeのM. J. Damzen. Applications of the Brillouin mirror for the control of high power lasersである。ブリルア ン散乱を用いて, レーザービームの質の向上, 強力化, パルス短縮, 広域 A S Eの除去が示さ れた。この種のブリルアン鏡はガスとか液体で あるから, 損傷しきい值が高く, 安価且つ大型 化が可能で, 増巾器間の結合防止にも使われる。 80気圧のメタンセルを用いすぐれた特性を得て いる。この応用は大出力ガラスレーザーの性能 向上に導入すべきものであろう。また位相共役 の発表はCLEOでも行われた。

次にレーザーによる同位体分離であるが, 最 も重要なのはウラン, プルトニウムの分離であ る。米国LLNLでは大規模な研究に発展中でレ ーザー核融合研究チームと略同一スケールのチ 一 ムAVLIS計画が嫁動している。ちなみに仏 では遠心分離方式を中止し、レーザー法に切り 換えた由である。L L Lの方法はいわゆる原子 法であって，U金属蒸気を銅蒸気レーザーポン プの色素レーザーで分離する方式である。150 $\mathrm{W}$ の銅蒸気レーザーは当初の寿命 4 時間から 1000 時間に延長され, 実用化研究が始まろうと している。

この他レーザー励起拡散に関するBrown大, Cold jet法による重金属の分光について理研， GTEにおける水銀の濃縮, OakRidgeの共鳴イ オン化による $\mathrm{Kr}$ 原子の分離などが報告され， 強い関心をあつめた。

(山中千代衛)

レーザー核融合用のエネルギードライバーと して稼動中のレーザーでは, 大阪大学の “激光 林号”が世界で最大出力を誇っているが, 米国 のカリフォリニア大学ローレンスリバモア国立 研究所 (略して LLNL) では出力 $100 \mathrm{~kJ}$ の大出 
カガラスレーザー “NOVA”を精力的に建設中 で，今年11月には爆縮実験を開始する予定であ る。これらの大出力ガラスレーザー光を K D P 結晶によって波長変換し, $2 \omega, 3 \omega, 4 \omega$ 光 を発生させる準備も各研究所で着々と進行して いる。また, 出力 $1 \mathrm{MJ}$ の大出力ガラスレーザ の設計も開始されており，このレーザーに用い られる光学部品を同時に開発している。

本報告では，主として核融合用大出力ガラス とその材料開発のセッションについて述べ，光 ファイバーについても簡単に触れる。

先づ, LLNLの発表を述べる。LLNLのD. Milam らは, 波長351，266，248 nm レーザ 用高耐力 AR 膜について報告した。この短波長 レーザー用高耐力AR膜は多孔性シリカ膜を基 板上に生成したもので，次の様な手法で膜を形 成する。(1)Fig. 1 に示すような化学構造式をも つポリマー溶液に石英基板を浸す，2窒素ガス 雲囲気中で基板をゆっくり引上げる，(3450 $500^{\circ} \mathrm{C}$ の酸素ガス炉で加熱し，膜中の炭素を除 去する, (4)0.0002 モルの HFでエッチングす る。以上の過程を経て多孔性シリカの AR 膜が 基板上に生成される。この AR 膜は, W estinghouse 社の研究開発センターで開発された。ガ ガラス基板の両面に曆さ 500 ～600 nm の AR 膜 を生成した場合に，波長350～1064nm の領域で の透過㳯は $99 \%$ 以上であったが，パルス幅0.6 $\mathrm{ns}$ ，波長 $355 \mathrm{~nm}$ でのレーザ一耐力は平均で2.1 $\mathrm{J} / \mathrm{cm}^{2}$ と低い值を示した。このため LLNLで引 き続き高耐力化を目ざして開発が行なわれた。 現状では，膜厚90nmに対してレーザー耐力は $6 \sim 9 \mathrm{~J} / \mathrm{cm}^{2}$ であり実用上使用できそうである

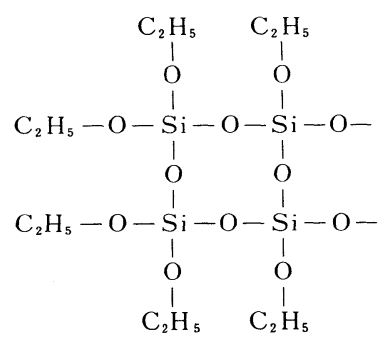

Fig. 1 Structual formula
が，問題点としては，AR膜面が比較的に柔ら かであるため，クリーニングペーパーなどを用 いて膜面を洗浄することができない，AR膜を 基板両面に施した場合の透過率は, Fig. 2 に示 すように入/4の単層膜と同じような特性を示す ため，広带域とならない。

現在大出力ガラスレーザーの励起用フラッシ ユランプには，セリウムを添加した石英管が使 用されている。L.P. Bsadley らは，溶融石 英管で製作されたフラッシュランプの点灯条件 と励起効率（レーザー出力 Plaser/ランプ入 力Plamp）の関係を調べた。本実験では，0.4 〜 $1 \mu \mathrm{m}$ の発光波長带域にわたって, ランプ入 力と発光スペクトル強度との関係を测定した。 この結果, ランプの爆発割合（ランプの入力エ ネルギー/ランプの爆発エネルギー） が0.1の

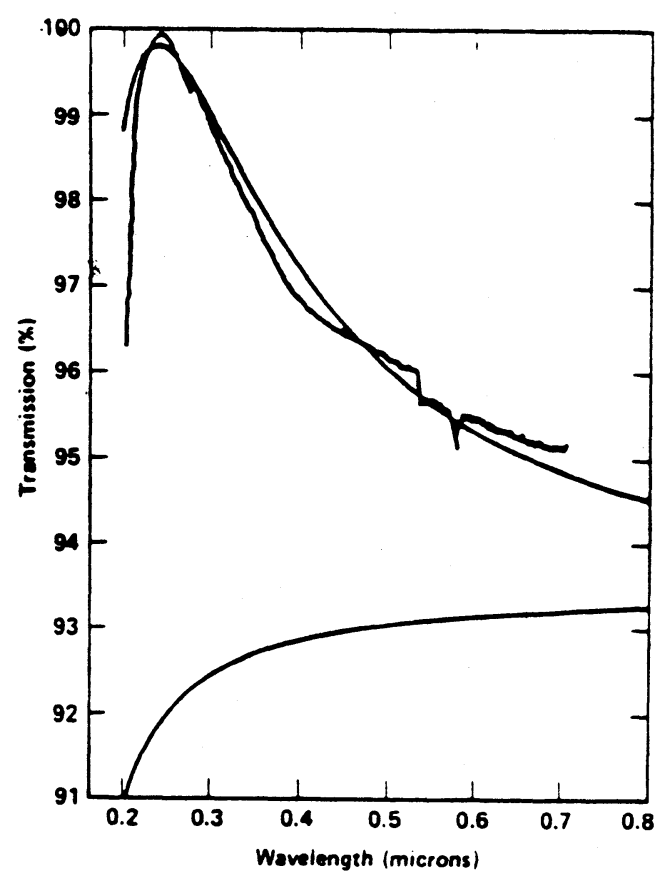

Fig. 2 Measured transmittance for a silica substrate with porous silica coatings on both surfaces. The smooth curve is calculated transmittance for a coating containing $52 \%$ silica and having a physical thickness of $47 \mathrm{~nm}$. The lower curve is transmittance for bare polished fused silica. 
時に, 最大励起効率は $16 \%$ になることが明らか にされた。実際のガラスレーザーではこのよう な高い励起効率は得られていないので, 今後は 新しい増幅器構造の高効率ガラスレーザーを開 発する予定である。

ディスクガラスの周囲には, パラスチック発 振防止用としてレーザーガラスと屈折率が等し く, $1.05 \mu \mathrm{m}$ 光を吸収するエッジコートを施し ていたが,この方法は光学的には優れているが, 非常に高価であるという久点があった。 J. E. Murray らは, 従来の方式にとって代るものと してシリコンラバーエッヂクラッディングを開発 した。Fig. 3 に示すように, 自然放出光を吸収 する吸収フィルターガラスをディスクガラスの 周囲におき，これをシリコンラバーでサンドイ ッチにする方式が採用された。使用されるシリ コンラバーは, フレネル反射が生じないように レーザーガラスやフィルターガラスと屈折が等 しいこと, 泡や散乱体がないこと, フラッシュ ランプや自然放出光によって損傷を受けないこ と, ディスクガラスに伝わる衝撃を吸収するこ と, 等の条件を備えることが必要である。市販

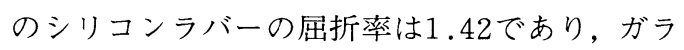
スの屈折率よりかなり低いのでメチル置換基と フェニル基を含む 2 種類のシロキサンモノマー を合成して作った。フェニル基の重量\%を $63 \%$ にするとシリコンラバーの屈折率は 1.52 となっ た。このシリコンラバーをロ径 $31.5 \mathrm{~cm}$ のディス ク増幅器用レーザーガラスに適用した所, $\alpha \mathrm{D}=$ 3.9 ( $\alpha$ : 小信号利得係数, D : 長軸の長さ) と なった。また, フラッシュランプ及びレーザー 光に対するレーザー耐力は，それぞれ $5 \mathrm{~J} / \mathrm{cm}^{2}$ と $15 \mathrm{~J} / \mathrm{cm}^{2}$ となり, 充分高い值を示すことが分

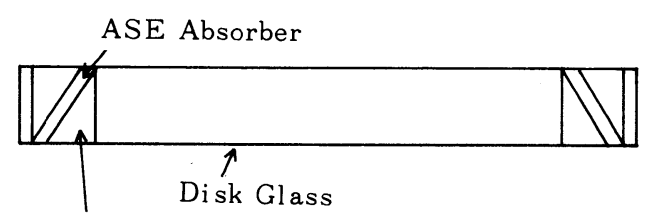

Silicone Rubber

Fig. 3 Silicone rubber edge cladding.
つた。

J. Goldhan らは，グロー放電電極を有する 大口径ポッケルスセルを開発した。従来のポッ ケルスセルはK D P 結晶の両端にリング状の電 極を設けてスイッチング電圧を印加していたが, この方式では口径が $10 \mathrm{~cm}$ 以上なると均一な電 場を印加する事が困難なため, 入力パターンと 同じ出力パターンを得ることができない。KDP 結晶の両面部分に 5 〜 Torr の He ガスを導 入してグロ一放電させ, $5 \times 5 \times 1 \mathrm{~cm}$ の $\mathrm{KD}^{*} \mathrm{P}$ ポッケルスセルにスイッチングパルス印加実験

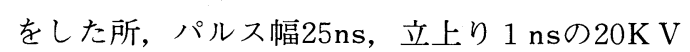
パルス電圧を発生させることができた。 Fig. 4 は, ポッケルスセルに電圧を印加するための 回路を示す。 2 台のサイライトロンがグロー放 電電圧とスイッチングパルス電圧を発生させる のに使用されている。次に, $27 \times 27 \mathrm{~cm}$ の KDP を使ったポッケルセルにグロー放電をさせたの ち, スイッチング電圧を印加してレーザー波形 を観測したところ, スイッチング電圧波形に相 当するレーザー波形を得ている。

非線形光学のセッションで興味深い発表は, 北テキサス州立大学の W. Williams らによっ て行なわれた波長 0.53 と $1.06 \mu \mathrm{m}$ のレーザー光 に対する非線形屈折率 $\mathrm{n}_{2}$ の測定である。サンプ ルガラス中で発生した位相歪みは, 自由空間を 伝搬させたビームの遠視野像を測定することに よって計算式を使って求めた。Table 1 に各材 料の $\mathrm{n}_{2}$ の値を従来の測定値と比較して示す。

光ファイバーに関しては, Bell研の A. R. Chraplyvy らは石英に $\mathrm{D}_{2}$ ガスを拡散させて $1.56 \mu \mathrm{m}$ で動作するラマンレーザーを発表した。 実験装置を Fig. 5 に示す。励起用光源として は, パルス幅120ps, 繰り返し $100 \mathrm{MHz}$ のモー ド同期YAGレーザーが使用された。 $1.06 \mu \mathrm{m}$ の励起によってファイバーからは, シリカから の $1.12 \mu \mathrm{m}$ の一次ストークスラマンと $\mathrm{D}_{2}$ から の $1.56 \mu \mathrm{m}$ の一次ストークスラマン光が放射さ れる。シリカのラマン利得は $\mathrm{D}_{2}$ の場合よりも 僅かに高いため, ポンピング光をシリカの発振 閾值より僅かに低く抑え, $1.56 \mu \mathrm{m}$ 光は光ファ 


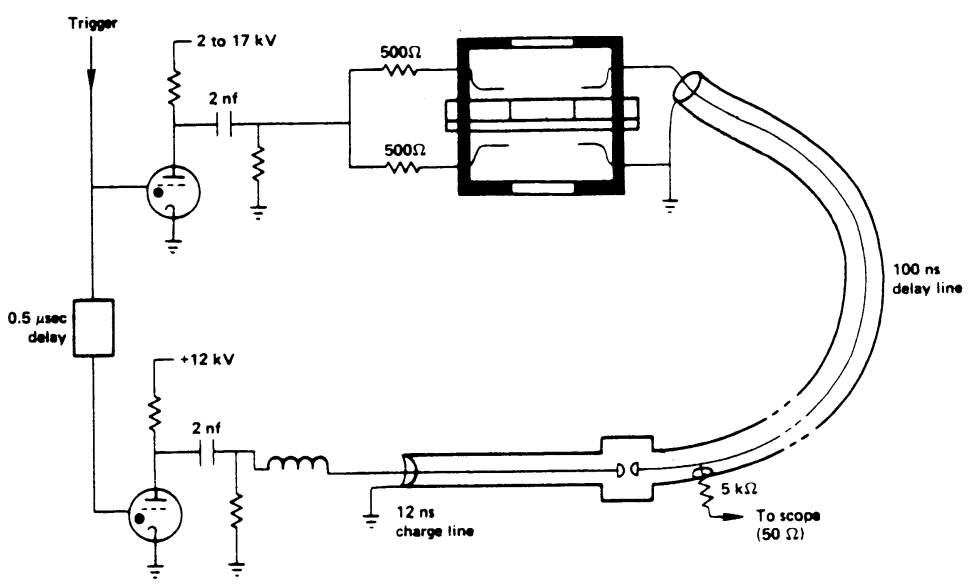

Fig. 4 Electrical circuit used to drive the $5-\times 5-\mathrm{cm}$ aperture plasma eiectrode Pockels cell.

イバーを数回以上通過させる事によって充分な 利得を得た。一例として，励起パワーが85Wの 場合， $1.56 \mu \mathrm{m}$ のピークパワーは $8 \mathrm{~W} て ゙ あ り ，$ スペクトル幅は $6.5 \mathrm{~cm}^{-1}$ であった。このスペク トル広がりは, ファイバー中での自己位相変調 による。

Table I. Measurements of $n_{2}$ at 0.53 and 1.06 $\mu \mathrm{m}^{\mathrm{a}}$

\begin{tabular}{cccc}
\hline Mateqial & $\begin{array}{c}\text { Wavelength } \\
(\mu \mathrm{m})\end{array}$ & $\begin{array}{c}\mathrm{n}_{2} \\
\left(\times 10^{-13} \text { esu }\right) \\
\text { This Work }\end{array}$ & $\begin{array}{c}\mathrm{n}_{2} \\
\left(\times 10^{-13} \text { esu }\right) \\
\text { Others Workers }\end{array}$ \\
\hline \multirow{2}{*}{$\mathrm{CS}_{2}$} & 1.06 & $128 \pm 10$ & $125 \pm 30^{(3)}$ \\
& 0.53 & $123 \pm 10$ & \\
$\mathrm{NaCl}$ & 1.06 & $1.37 \pm 0.15$ & $1.22 \pm 0.21^{(4)}$ \\
& 0.53 & $1.38 \pm 0.13$ & \\
$\mathrm{SiO}_{2}$ & 1.06 & $0.62 \pm 0.03$ & $0.95 \pm 0.10^{(4)}$ \\
& 0.53 & $0.60 \pm 0.04$ & \\
$\mathrm{BK}^{2} 7$ & 1.06 & $1.45 \pm 0.15$ & $1.46 \pm 0.10^{(1)}$ \\
& 0.53 & $1.01 \pm 0.08$ &
\end{tabular}

a) The errors shown for this work are relative errors deduced from scatter in the data over many measurements. The dispersion in $n_{2}$ is expected to be accurate to within the error bars shown, since absolute errors, such as energy measurements, are expected to be the same at both wavelengths.

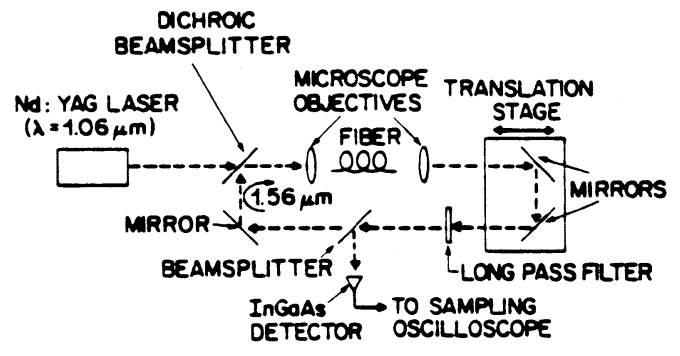

Fig. 5 Schematic diagram of synchronously pumped gas-in-glass laser. The dichroic beam splitter transmits $1.06-\mu \mathrm{m}$ and reflects $1.56-\mu \mathrm{m}$ light. The long-pass filter passes $1.56 \mu \mathrm{m}$ and suppresses silica Stokes at $1.12 \mu \mathrm{m}$.

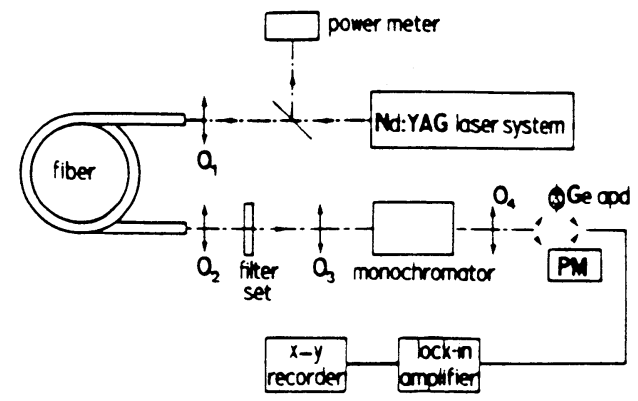

Fig. 6 Experimental setup. Two detectors have been used when recording the spectrum of the output light. A germanium avalanche photodiode ( $\mathrm{Ge}$ apd) and a photomultiplier ( $\mathrm{PM}$ ). $\mathrm{O}_{1}-\mathrm{O}_{4}$ are microscope objectives and lenses. 


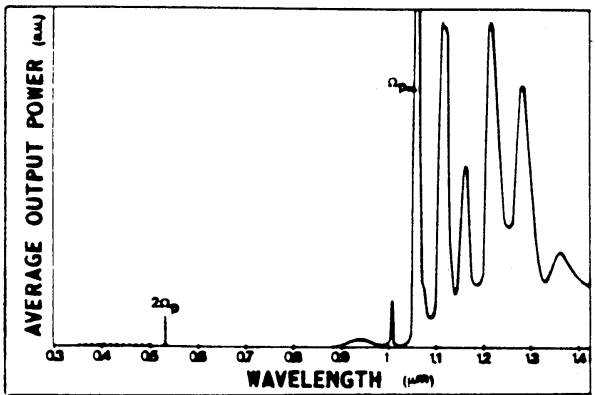

Fig. 7 Spectrum of the output light. The dotted line represents the third harmonic light emission, the power level of which is $20 \mathrm{~dB}$ below the $532-\mathrm{nm}$ line. $\Omega p$ is the pump frequency.

フランスの CGE 研究センターの J. M.

Gobriagues らは，長さ $10 \mathrm{~m} の \mathrm{GeO}_{2}-\mathrm{SiO}_{2}$ 棈 円形ファイバーにモード同期 $\mathrm{Q}$ スイッチ $\mathrm{YAG}$

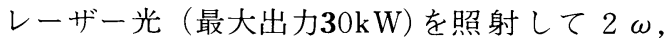
$3 \omega$ 光の発生を観測した。平均コア径は $4.6 \mu \mathrm{m}$ 楕円率は $10 \%$ である。実験装置を Fig. 6 に, ファイバーの出力端からの放射光スペクトルを Fig. 7 に示す。900-1500nm のIR スペクトル は, 誘導ラマン散乱及び 4 光子混合過程により 生じたものである。 $2 \omega$ と $2 \omega$ より約 $20 \mathrm{~dB}$ 低 い $3 \omega$ 光が発生したが, これらの高調波はファ イバーの軸方向に沿って発生したものでなく, ファイバーのクラッド内を伝搬している。

スタンフォード大学のM. M.Feier らは, 単 結晶ファイバーの成長について報告した。Fig. 8 に単結晶ファイバーを成長させるための方法 を示す。 $\mathrm{CO}_{2}$ レーザーを軸方向に対称となるよ うに全周から照射して種結晶を除々に引き上げ る。成長速度は $1 \sim 10 \mathrm{~mm} / \mathrm{min}$ である。この方 法によって 5 種類の単結晶ファイバー $\left(\mathrm{Al}_{2} \mathrm{O}_{3}\right.$, Ti: $\mathrm{Al}_{2} \mathrm{O}_{3}, \mathrm{Cr}: \mathrm{Al}_{2} \mathrm{O}_{3}, \quad \mathrm{Nd}: \mathrm{YAG}$, and $\mathrm{LiNbO}_{3}$ ) を成長させた。例えば, $5 \mathrm{~cm}^{2} \times$ $25 \mu \mathrm{m}^{\Phi}$ の $\mathrm{LiNbO}_{3}$ の場合, 直径の変位 $1 \%$ に対 し光学的損失は約 $0.5 \%$ と評価された。また, $5 \mathrm{~cm}^{2} \times 170 \mu \mathrm{m}$ のルビーファイバーでは, $632.8 \mathrm{~nm}$ における光学的伝送損失は $0.044 \mathrm{~dB}$ / cmであった。この実験においては,クラッデ

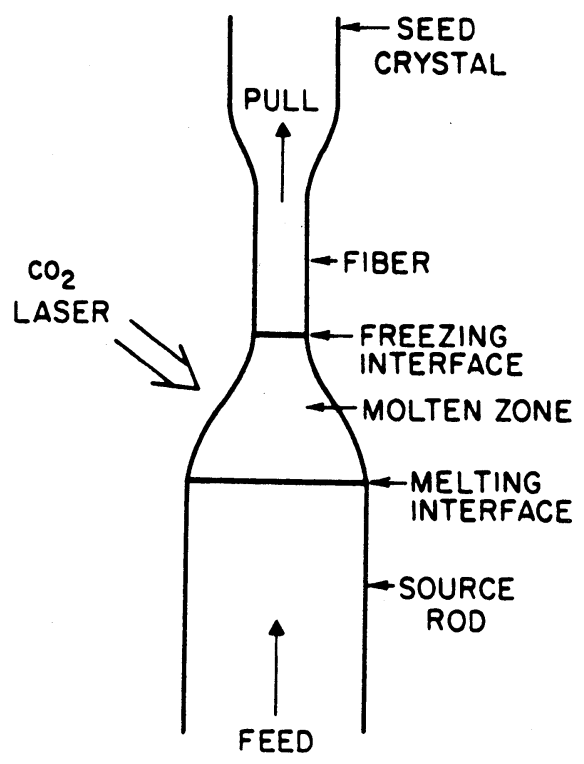

Fig. 8 Schematic diagram depicting fiber growth. イングは使われていない。

（吉田国雄）

今回二つの会議に出席し, 特に感じられたの はIQECより CLEOの方が大いに勢況であった という事である。レーザーの実用化が大幅に進 んでいる現状では，己れは当然の結果かも知れ ない。大学サイドの研究者は今こそオリジナル な研究を行うべきであるという思いを強く持っ た。また中国からの参加者がずい分多かった。 CLEOのレーザー展示ショーではブースも出て おり，いかにも現在の中国の現状を反映してい る感じがした。レーザーの基礎的な幅広い研究 が盛んに行なわれているようで将来ののびを感 じさせた。

筆者が分担した調査範囲の中から, 非線形光 学結晶, 新固体レーザーについて, 二・三トピ ックスを紹介する。

\section{1. 非線形光学結晶}

今回新しい非線形光学材料として注目された のは $\beta-\mathrm{BaB}_{2} \mathrm{O}_{4}$ 結晶である。この他には $\mathrm{KTP}$ 
$\left(\mathrm{KTiOPO}_{4}\right)$ のレーザー特性について何件かの 報告があった。

\section{$1.1 \beta-\mathrm{BaB}_{2} \mathrm{O}_{4}$ 結晶}

中国科学院福建物質結构研究所所長の Chen ChuangtianがIQECで招待講演として報告した。 お世辞にも上手な英語とは云えないが，極めて 情熱的に，かつ大きな声で話しているのが印象

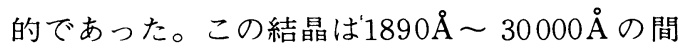
に透過領域を有し，かつ非線形定数がK D P の 数倍あるという事で紫外域の高効率高調波発生

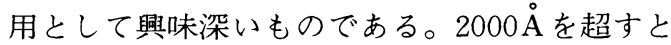
効率の良い波長変換素子は現在殆んどないと云 つてよため, 紫外へ, 紫外へと研究の対象が 向いている現在，大いに注目を注びたものと思 われる。

結晶構造はR 3 グループに属し格子定数は, $a=b=12.532 \AA, \quad c=12.71 \AA$ 円゙ある。 High temperature solution による Top seeding methodで製作され, Melting point $1095^{\circ} \mathrm{C}$, Transition temperature $925 \pm 5{ }^{\circ} \mathrm{C}$, モース 硬度 4 ということである。值径 $30 \mathrm{~mm}^{\phi}$, 厚さ 10 $\mathrm{mm}$ の結晶の写真を示していた。非常に透明度が

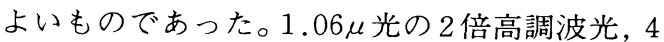
倍高調波光に対する位相整合角と実効非線形光 学定数 deff t Table 2 に示す。温度位相整合も可 能で, $1.06 \mu$ 光に対し整合温度中心が約 $450^{\circ} \mathrm{C}$, 整合半值幅が約 $100^{\circ} \mathrm{C}$ もある。变換効率の実験は 出力 $15 \mathrm{MW}$ の $1.06 \mu$ 光を用いて行なわれており, 結晶長 $4.3 \mathrm{~mm} の \beta-\mathrm{BaB}_{2} \mathrm{O}_{4}$ に対し $\eta=35 \%$ が 得 られている。これに対し $30 \mathrm{~mm} の \mathrm{KDP}$ では $=39$ \%であった。これより K D Pよりもかなり効率 が高い事が分る。レーザー損傷閾値は出力 150 $\mathrm{mJ}, 7.5 \mathrm{~ns}$ のスイッチ $\mathrm{YAG}$ スーザー光により

Table 2 Phase matching angle and nonlinear optical constant of $\beta-\mathrm{BaB}_{2} \mathrm{O}_{4}$

\begin{tabular}{|c|c|c|}
\hline & $\begin{array}{c}2 \omega \\
1.06 \mu \rightarrow 0.53 \mu\end{array}$ & $\begin{array}{c}4 \omega \\
0.53 \mu \rightarrow 0.266 \mu\end{array}$ \\
\hline$\theta \mathrm{m}$ & $21^{\circ}$ & $48^{\circ}$ \\
\hline $\begin{array}{c}d_{\text {eff }} \\
\text { (計算値) }\end{array}$ & $\begin{array}{c}3.46 d_{36} \\
\text { of KDP }\end{array}$ & $\begin{array}{c}2.51 d_{36} \\
\text { of KDP }\end{array}$ \\
\hline
\end{tabular}

求めており約 $2 \mathrm{GW} / \mathrm{cm}^{2}$ で十分高出力に耐え得 るものと思われる。紫外域での実験はまだなさ れていないようである。

\section{$1.2 \mathrm{KTP}$ 結晶}

KTP (Potassium Titanate Phosphate : $\left.\mathrm{KTiOPO}_{4}\right)$ 自体は以前に報告された結晶であ るが, バナナ $\left(\mathrm{Ba}_{2} \mathrm{Na}_{2} \mathrm{Nb}_{5} \mathrm{O}_{15}\right)$ と同程度の非 線形光学定数を持ち, かつ吸湿性がない, 熱的 に安定, レーザー耐損傷性が $100 \mathrm{MW} / \mathrm{cm}^{2}$ 以上 で高い等の理由から，これを用いて安定な高繰 返し, 高出力のグリーン光 $(0.53 \mu)$ を得よう とする方向での研究がなされている。紫外光発 生は透過の点から用いる事ができない。用途と して紫外光発生の為の光源, 加工, 医用があり, メーカーサイドが力を入れている。

結晶はOrthorhombic構造， 2 軸性でhydrothermalに育成される。

XMR Inc.ではNd: YAGレーザーの C W 励 起, $20 \mathrm{kHz}$ QスイッチングでKTPを共振器内 に入れる方法により平均 $9 \mathrm{~W}$ ○ $0.53 \mu$ 光を得て いる。彼等はこれにより, $\mathrm{GaAs}, \mathrm{Si}, \mathrm{Cu}, \mathrm{Au}$ 等のカッティングを行なった結果を示した。こ のほかMelanin, Hemogrobin, Xanthophyll等 の色素が $0.53 \mu$ で $80 \%$ 以上の吸収を持つため医 用に有効であることを指適していた。

General Electric社も同じように CW 励起 した Nd:YAGレーザーの $5 \mathrm{kHzQ}$ スイッチング 光で夕イプII KTP（結晶長 $3.5 \mathrm{~mm}$ ) を用い $6 \mathrm{~W}$ のグリーン光を得ている。同一励起の $\mathrm{LiIO}_{3}$ （タイプ I， 10mm長）では $2 \mathrm{~W}$ 位が得られたが, レーザー損傷のためこれ以上の出力を得ること ができず，K T Pの優位性を示していた。

この他 Quantronix Corp. から Type IIの KTPをダブラーに， Type II $\mathrm{KD}^{*} \mathrm{P}$ をリプ ラーに用いた高繰返し紫外光 $(0.35 \mu)$ 発生の 結告があった。Fig. 9 にその発生方法を示す。 これはpolarization mismatch methodと称す るものでレーザー核融合で 3 倍波の高効率変換 法として採用された手法である。出力 $1.2 \mathrm{MW}$ $(120 \mathrm{~mJ})$ の $1.06 \mu$ を用い 2 倍波で $0.61 \mathrm{MW}$ 


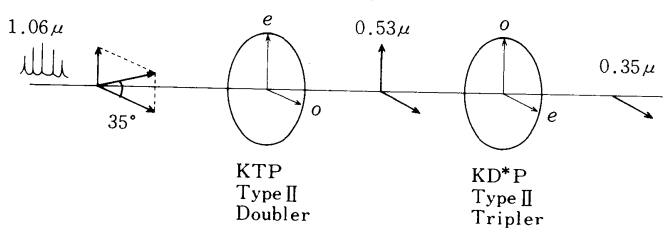

Fig. 9 Frequency tripling scheme with type II crystals.

$(61 \mathrm{~mJ}) ， 3$ 倍波で $0.18 \mathrm{MW}(18 \mathrm{~mJ})$ を得てい る。KTPは $3 \times 3 \times 5.3^{l} \mathrm{~mm}, \mathrm{KD}^{*} \mathrm{P}$ は $12 \times 12$ $\times 30^{l} \mathrm{~mm}$ のものを用いた。

その他に水溶性結晶の表面処理としてローレ ンスリバーモア研究所から K D Pのコーティン グに関する発表があった。エチレンテトラシリ ケートの加水分解を用い $\mathrm{SiO}_{2}$ 膜をコートする もので温度を上げてコートできないK D P等に は有効な手法である。レーザー耐損傷性も 0.35 $\mu$ 光に対し $4 \mathrm{~J} / \mathrm{cm}^{2}$ 以上が得られている。ただ現 時点ではメカ二カルに極めて弱く, 触れる事が できないという久点がある。他の材料にもいろ いろ応用できそうな方法で興味が持たれた。

\section{2. 新固体レーザー}

新固体レーザーが近年盛んに研究されるに至 つている。1つはレーザー核融合用エネルギー ドライバーとして高出力, 高繰返しを固体レー ザーにより得ようとする動きである。もう 1 つ
は加工, 医用, 分光等を主とした産業用として 従来のY A Gレ・-ザーを上まわる高効率, 高繰 返し, Tunableなレーザーを得ようとする動き である。CLEOではこの種の関係の発表が招待 講演 3 件を含み約 20 件あった。Tunabilityを得 るために Cr, Ti, Co等のイオンを添加した材 料と, 高効率化を目的にCrイオンのエネルギー 移動を利用した Nd:レーザー材料の 2 つの研究 が行なわれている。レーザー媒質の形状に関し ては高繰返し時における熱的歪を小さくするた め, 従来のロッド型のものに代わり, スラブ形 状, Active Mirror 形状のものが試みられ, 高効率高出力のものが得られ始めている。加工 用には終局的に $1 \mathrm{~kW}$ 以上の平均出力を得る事 を目標としている。

\section{1 新固体レーザー材料}

ローレンスリバーモア研究所のW.F.Krupke と MIT. Lincoln 研究所の P. F. Moulton の 2 名 がCLEOで招待講演を行なった。

Table 3 は Tunable solid state laser とし て会議で報告されたものについて材料と動作波 長についてまとめたものである。Crを添加した GSGG, GGG, エメラルド, アレキサンドライ 卜等は実用段階に近いが，その他の Co, Ti 等 を添加した材料については小片の結晶について レーザー発振が得られている程度である。

高出力, 高効率用材料としては $\mathrm{Cr}$ を添加し

Table 3 Tunable solid state lasers.

\begin{tabular}{|c|c|c|}
\hline laser material & Operating Wavelength $(\mathrm{nm})$ & Pump. Source \\
\hline $\mathrm{Cr}^{3+}: \mathrm{GSGG}(\mathrm{Gd}, \mathrm{Sc}, \mathrm{Ga}$ Garret $)$ & $745-820$ & lamp \\
\hline $\mathrm{Cr}^{3+}:$ GGG $\quad(\mathrm{Gd}, \mathrm{Ga}$ Garret $)$ & 760 & lamp \\
\hline $\mathrm{Cr}^{3+}$ : Emerald $\left(\mathrm{Be}_{3} \cdot \mathrm{Al}_{2}\left(\mathrm{SiO}_{3}\right)_{6}\right)$ & $751-759$ & lamp \\
\hline $\mathrm{Cr}^{3+}:$ Alexandrite $\left(\mathrm{BeAl}_{2} \mathrm{O}_{4}\right)$ & $701-818$ & lamp \\
\hline $\mathrm{Cr}^{3+}: \mathrm{Na}_{2} \mathrm{Li}_{3} \mathrm{Ga}_{2} \mathrm{~F}_{12}$ & 776 & Dye laser \\
\hline $\mathrm{Cr}^{3+}: \mathrm{KZnF}_{3}$ & 880 & Dye laser \\
\hline $\mathrm{Co}: \mathrm{MgF}_{2}$ & $1500-2300$ & $1.33 \mu \mathrm{Nd}: \mathrm{YAG}$ \\
\hline $\mathrm{Co}: \mathrm{KMgF}_{2}$ & $\left(77^{\circ} \mathrm{K}\right)$ & \\
\hline $\mathrm{Ti}: \mathrm{Al}_{2} \mathrm{O}_{3}$ & $660-986$ & Dye laser \\
\hline $\mathrm{Ti}: \mathrm{YAlO}_{3}$ & & \\
\hline
\end{tabular}


た Nd:GSGGレーザー（またはGGGレーザー） が最も期待できる。Y A G と異なり結晶育成時 に中心にコアを持たないため断面の大きなもの を得ることが容易であり，かつバブルメモリ 一として素材的に大分以前から大型の結晶が製 作されていたこと等がこの種のレーザーが最も 進んでいる理由と思われる。

Krupkeの報告では $5^{\phi} \times 50 \mathrm{~mm}^{2}$ のロッドを用 いてノーマル発振で効率 $4.5 \%$ (出力 $0.2 \mathrm{~J}$ ) を得 ている。 Nd濃度は $2 \times 10^{20} \mathrm{ion} / \mathrm{cc}, \mathrm{Cr}$ 濃度は $2 \times 10^{20} \mathrm{ion} / \mathrm{cc}$ である。同じ装置でYAGの場合 は効率 $1.9 \%$ 程度であった。Moulton の報告で は $5^{\phi} \times 75 \mathrm{~mm}^{2}$ の GSGGを用い繰返し $20 \mathrm{~Hz}$ で平 均40Wの出力を得ており Y A Gに較べ約 2 倍の $5 \%$ 変換効率であった。GSGG, GGGはYAG に較べ熱的歪がやや大きい。GTE Goverment Systems が熱的集束効果は約 6 倍高いと報告し ていた。また励起ランプの紫外光による Solarizationの問題もあるようである。

\section{2 スラブ型レーザー}

スラブ形レーザーの概念を Fig. 10 (a ) に示す。 レーザービームを媒質中でジグザグに全反射さ

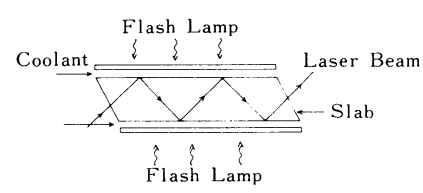

(a) Slab laser

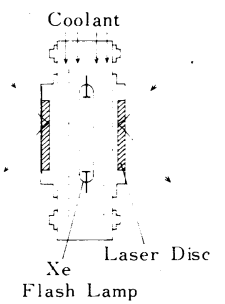

(b) Active mirror amplifier
Fig.10 Two types of high repetition laser.
せながら通すことにより媒質中における場所的 な熱歪みをキャンセルするもので従来のロッド 型より高繰返し, 高出力が期待できる。

ローレンスリバーモア研究所のJ.L.Emettは CLEOで"Potential of Solid State Lasers for High-Average Power Applications” と 題する招待講演を行なった。彼等はレーザー核 融合ドライバーとして固体レーザーを用いる事 を真剣に検討している。レーザー媒質中での Symmetry energy deposition が極めて重要 でありFig.10(a)に較べ(b)のActive Mirror 型では対称性を欠く点から問題があることを指 摘していた。レーザー媒質に 2 気圧の $\mathrm{He}$ ガス を冷却剤として用い $100 \mathrm{~kW} / \mathrm{m}^{2}$ の熱除去が行な える等各種のレーザー材料に対する高繰返し， 高出力レーザーの検討結果を報告していた。

スラブ型レーザーの家験としては General Electric 社の招待講演があげられる。彼等は $6.4 \times 45 \times 250 \mathrm{~mm}$ の LHG 5 スラブガラスを用い $10 \mathrm{~Hz}$ 繰返し $\mathrm{Q}$ スイッパルスで2.5 J $(25 \mathrm{~W}$ 平 均）を得ている。また $8 \times 16 \times 128 \mathrm{~mm}$ のスラブ 型YAGで $320 \mathrm{~Hz}$ 繰返しQスイッチパルスで0.25 J、(80W平均) を得ている。住友金属鉱山(株) か らは $7 \times 35 \times 115 \mathrm{~mm}$ のスラブ型 GGGの発振特性 が報告された。TRW Inc.はActive Mirror 型の増幅装置を発表した。 $80^{\phi} \times 12^{t} \mathrm{~mm}$ の LHG 5 ディスクガラスを 2 枚用い $13 \mathrm{~mm}{ }^{\phi}$ の $\mathrm{Xe}$ ランプ 6 本で励起, 出力として $5 \mathrm{~Hz}$, 平均 $120 \mathrm{~W}$ を得 ていた。

今後 GSGG, GGGの新素材を用いたこの種 のレーザーの大型化が進み出力 $1 \mathrm{KW}$ Wーザー の出現は時間の問題と思われる。

(佐々木孝友) 